\title{
A study on the fabrication of foamed glass by using refused coal ore and its physical properties
}

\author{
Tae-Young Lim ${ }^{\dagger}$, Hyun-Woo Ku, Jonghee Hwang, Jin-Ho Kim and Jung-Kook Kim* \\ Korea Institute of Ceramic Engineering \& Technology, Seoul 153-801, Korea \\ *Kangwon National University, Samcheok 245-711, Korea
}

(Received October 21, 2011)

(Revised November 9, 2011)

(Accepted November 18, 2011)

\begin{abstract}
Foamed glass was fabricated by using glass powder and foaming agents. For the glass powder, we used sodalime glass which's manufactured by using refused coal ore obtained as by-product from Dogye coal mine in Samcheok. And for the foaming agents, we used Calcium carbonate, Calcium phosphate and powder of shale type refused coal ore itself which has high content of carbon materials. We additionally used liquid binder for forming, and mixed together. And we formed rectangular shape and treated $800^{\circ} \mathrm{C}$ for $20 \mathrm{~min}$ in an electrical furnace. The various kinds of foam glass samples were fabricated according to the kinds of foaming agents. The physical properties of samples, as specific gravity and compressive strength, were measured. Pore structure of each samples were investigated too. Foam glass with specific gravity of $0.4 \sim 0.7$ and compressive strength of $30 \sim 72 \mathrm{~kg} / \mathrm{cm}^{2}$. Especially we get satisfying foam glass sample with low specific gravity of 0.47 and high compressive strength of $72 \mathrm{~kg} / \mathrm{cm}^{2}$ by the use of liquid calcium phosphate as foaming agent. It also had small and even shape of pore structure. Therefore, it is concluded that refused coal ore can be used for raw materials to manufacture secondary glass products such as a foamed glass panel for construction and industrial materials.
\end{abstract}

Key words Foam glass, Refused coal ore, Soda-lime glass, Foaming agents, Physical properties

\section{석탄 폐석을 이용한 발포유리의 제조 및 물리적 특성 연구}

임태영", 구현우, 황종희, 김진호, 김정국*

한국세라믹기술원 전자/광소재센터, 서울, 153-801

*강원대학교 삼척캠퍼스 삼척유리특성화사업단, 삼척, 245-711

(2011년 10월 21일 접수)

(2011년 11월 9일 심사완료)

(2011년 11월 18일 게재확정)

요 약 삼척 도계지역의 탄광에서 석탄채취 시에 부산물로 발생되는 석탄폐석을 원료로 하여 제조된 분말유리와 다양 한 종류의 발포제를 활용하여 발포유리를 제조하였다. 유리는 소다라임계 화학조성을 갖는 유리였고, 유리분말에 발포제로 서 탄산칼슘, 인산칼슘, 그리고 석탄폐석 중 카본함량이 높은 셰일(shale) 계의 석탄폐석분말을 사용하였고, 이들 원료에 액 상 바인더를 첨가하여 혼합한 후, 판상의 형태로 성형하였다. 성형체를 건조한 후 전기로에서 $800^{\circ} \mathrm{C} 20$ 분간 열처리함으로 써 다공성의 발포유리 패널을 제조할 수 있었다. 발포제의 종류에 따라 다양한 특성을 갖는 발포유리샘플이 제조되었으며, 이들의 비중 및 압축강도와 같은 물리적 특성을 측정하였고, 기공의 크기 및 형태를 현미경으로 관찰하였다. 석탄폐석으로 제조한 폐유리를 활용하여 비중 0.4 0.7, 압축강도 $30 \sim 72 \mathrm{~kg} / \mathrm{cm}^{2}$ 를 갖는 발포유리 샘플을 얻을 수 있었으며, 특히 액체인산 칼슘 발포제를 사용하여 0.47 의 낮은 비중과 $72 \mathrm{~kg} / \mathrm{cm}^{2}$ 의 높은 압축강도를 갖는 발포유리를 얻을 수 있었다. 따라서 삼척지 역에 폐기된 다량의 석탄폐석이 건축용 및 산업용 발포유리 2 차 제품을 제조하는데 충분히 활용이 가능하리라 판단되었다.

\footnotetext{
Corresponding author

Tel: +82-2-3282-2426

Fax: +82-2-3282-7817

E-mail: tylim@kicet.re.kr
} 


\section{1. 서 론}

우리나라 에너지 자원산업의 근간이 되어온 석탄산업 은 국민 생활수준의 향상 및 청정연료의 공급증대로 인 하여 그 역할이 많이 감소하여, 현재 가행탄광의 수는 1988년 347개소에서 2004년도에는 9개소로 약 $97.4 \%$ 가 감소하였다[1]. 석탄광의 개발에 따라 부수적으로 발 생하는 석탄폐석이 그 동안 다량 발생되었으나, 마땅한 재활용방법이 개발되지 않았고 단순 매립처리도 어려운 실정이어서 탄광지역 주변에 야적된 상태로 방치된 상태 로 장기간 동안 근본적인 처리가 이루어지지 않았기 때 문에 오늘날 주변경관 훼손과 함께 자연환경의 위해 요 인으로 작용되고 있다. 석탄합리화 사업단이 조사 집계 한 국내 석탄폐석 관련 자료에 의하면, 1989년부터 1993 년까지 폐광된 석탄광의 경우 약 2 억 톤의 폐석이 발생 되어 적치되어 있고, 현재까지 가용해오고 있는 9 개소의 탄광에서도 3,600 만 톤이 발생되어 적치되어 있는 것으 로 보고되고 있다[2].

그 동안 폐자원에 대한 재활용 연구는 주로 화력발전 소에서 발생하는 석탄 회나 하수 슬러지 등을 이용하여 인공경량골재를 제조하는 연구들이 많이 수행되어 왔다 [3-5]. 그러나 본 연구에서는 광산에서 발생하는 석탄폐 석을 활용하여 석탄폐석에 함유된 실리카 $\left(\mathrm{SiO}_{2}\right)$ 성분을 기본으로 타 원료를 조합한 후 용융하여 유리화를 시키 고 제조된 유리를 이용하여 건축재료로 활용할 수 있는 유리타일이나 발포유리 패널과 같은 2 차 제품을 개발함 으로써 환경도 살리고 폐자원의 부가가치도 높일 수 있 다는 면에 중점을 두고 이 연구를 진행하였다. 파유리를 이용하여 제조하는 유리 2차제품의 하나로서 발포유리 다공체 제조기술을 기반으로 한 건축용 단열패널이나 경 량골재 제품을 제조하는 연구들이 그 동안 많이 이루어 져 왔다[6-8]. 이러한 제품은 기존의 스치로폼과 같은 유 기계 단열재에 비해 불연성이고 화재 시에도 유독가스를 발생시키지 않는 등 대표적 친환경소재이면서 유리섬유 나 ALC(Autoclaved Lightweight Concrete)를 이용하여 제조된 무기계 단열재보다 강도 및 가격 면에서 우수한 무기계 단열재이기 때문에 최근 많은 관심과 함께 그 응 용범위 및 시장규모가 크게 확대되고 있다. 본 연구에서
는 일반 파유리보다도 자원재활용 차원에서 친환경적이 며, 경제성이 우수한 석탄폐석활용 유리를 이용하여 발 포유리제품의 제조가능성을 파악하고자 하였다.

이미 1 차 연구를 통해 석탄폐석을 이용한 소다라임계 유리를 제조하였으며, 이들의 열적, 광학적 특성과 같은 각종 물리적 특성에 대해서도 연구를 진행하였다 $[9,10]$. 본 연구에서는 이러한 1 차 연구결과를 토대로 다양한 유리 2 차 제품으로의 활용을 위해 삼척의 도계탄광지역 에서 발생한 석탄폐석으로 제조된 소다라임계 유리를 분 쇄하여 분말화하고, 여기에 다공성의 발포유리 구조체를 형성시키기 위한 발포제로서 탄산칼슘, 인산칼슘(분말상), 인산칼슘(액상) 등의 화학원료 및 석탄폐석 중 탄소성분 을 많이 포함하고 있는 셰일(shale)계 석탄폐석 자체 분 말을 사용하였다. 또한 무기바인더를 첨가하여 패널형태 의 성형체를 제조하였고, 열처리를 통해 발포 다공체를 제조하였다. 다양한 종류의 발포제 종류 및 함량에 따라 다공체가 갖는 발포특성 및 기공의 구조를 분석하였으며, 다공체가 갖는 비중, 압축강도와 같은 물리적 특성을 측 정하였다.

\section{2. 실험방법}

일반적으로 석탄폐석은 발생 형태에 따라 굴진과정에 서 배출된 굴진폐석(digging refuse)과 선탄과정에서 발 생된 선탄폐석(coal-preparation refuse)으로 구분할 수 있다[1]. 본 연구에서는 그 중 선탄폐석을 사용하였으며, 선탄폐석 중에서도 일반 선탄경석과 카본 함량이 좀 더 많아 검은 색을 띄는 셰일(shale) 선탄경석의 두 종류를 사용하였다. 발포유리 제조를 위한 주 원료인 분말유리 제조를 위해서는 일반선탄경석을 이용하였고, 셰일 선탄 경석은 발포제로서 일부 배합에 활용하였다.

본 연구에서 사용한 두 종류의 석탄폐석과 이를 이용 해 제조한 소다라임계유리의 화학성분을 Table 1 에 나타 내었으며, 석탄폐석으로 만들어진 유리를 RCO-Glass (Refused Coal Ore-Glass)라고 임의로 명명하였다. 또한 이러한 RCO-Glass를 사용하여 발포유리를 제조하기 위 한 샘플별 배합비를 Table 2에 요약하여 나타내었다. 일

Table 1

Chemical composition of refused coal ore and RCO-glass (wt\%)

\begin{tabular}{llllllllllll}
\hline & $\mathrm{SiO}_{2}$ & $\mathrm{Al}_{2} \mathrm{O}_{3}$ & $\mathrm{CaO}$ & $\mathrm{MgO}$ & $\mathrm{Fe}_{2} \mathrm{O}_{3}$ & $\mathrm{~K}_{2} \mathrm{O}$ & $\mathrm{Na}_{2} \mathrm{O}$ & $\mathrm{MnO}$ & $\mathrm{TiO}_{2}$ & $\mathrm{SO}_{3}$ & $\mathrm{C}$ \\
\hline Refused coal ore (Normal) & 78.9 & 11.7 & 0.06 & 0.27 & 0.50 & 3.27 & 0.18 & 0.003 & 0.50 & 1.91 & 2.67 \\
Refused coal ore (Shale) & 62.7 & 16.4 & 0.20 & 1.01 & 2.99 & 3.27 & 0.19 & 0.04 & 1.54 & 0.33 & 11.3 \\
Normal glass (Soda-lime glass) & 71.3 & 2.00 & 9.46 & 1.99 & 0.30 & 0.75 & 13.4 & - & - & 0.10 & - \\
RCO-Glass & 71.4 & 2.71 & 9.69 & 1.36 & 0.46 & 0.67 & 13.5 & 0.01 & 0.07 & - & - \\
\hline
\end{tabular}

※ RCO-Glass: Soda lime glass which's made by refused coal ore. 
Table 2

Batch composition of foam glass samples

\begin{tabular}{|c|c|c|c|c|c|c|c|c|c|c|c|}
\hline & \multicolumn{7}{|c|}{ Raw materials (powder) } & \multicolumn{4}{|c|}{ Raw materials (solution) } \\
\hline & $\begin{array}{l}\text { Normal } \\
\text { glass }\end{array}$ & $\begin{array}{l}\text { RCO- } \\
\text { glass }\end{array}$ & $\begin{array}{l}\text { Filler } \\
\text { (diatomite) }\end{array}$ & $\begin{array}{l}\text { Calcium } \\
\text { carbonate }\end{array}$ & $\begin{array}{l}\text { Calcium } \\
\text { phosphate }\end{array}$ & $\begin{array}{l}\text { Coal_ore } \\
\text { (shale) }\end{array}$ & Total & $\mathrm{NaOH}$ & $\begin{array}{l}\text { Sodium } \\
\text { silicate }\end{array}$ & $\begin{array}{l}\text { Calcium } \\
\text { phosphate }\end{array}$ & Water \\
\hline NG-C/Pp & 60 & $\mathbf{0}$ & 30 & 5 & 5 & $\mathbf{0}$ & 100 & 10 & 20 & $\mathbf{0}$ & 12 \\
\hline $\mathrm{RCO}-\mathrm{C} / \mathrm{Pp}$ & $\mathbf{0}$ & 60 & 30 & 5 & 5 & $\mathbf{0}$ & 100 & 10 & 20 & $\mathbf{0}$ & 12 \\
\hline $\mathrm{RCO}-\mathrm{C} / \mathrm{S}$ & $\mathbf{0}$ & 60 & 30 & 5 & $\mathbf{0}$ & 5 & 100 & 10 & 20 & $\mathbf{0}$ & 12 \\
\hline RCO-S/Pp & $\mathbf{0}$ & 60 & 30 & $\mathbf{0}$ & 5 & 5 & 100 & 10 & 20 & $\mathbf{0}$ & 12 \\
\hline $\mathrm{RCO}-\mathrm{S}$ & $\mathbf{0}$ & 60 & 30 & $\mathbf{0}$ & $\mathbf{0}$ & 10 & 100 & 10 & 20 & $\mathbf{0}$ & 12 \\
\hline RCO-Ps & $\mathbf{0}$ & 70 & 30 & $\mathbf{0}$ & $\mathbf{0}$ & $\mathbf{0}$ & 100 & 10 & 3 & 22 & $\mathbf{0}$ \\
\hline
\end{tabular}

반적으로 상업적인 발포유리를 제조하기 위한 발포제로 서 탄산칼슘 및 카본이 가장 많이 사용되고 있으며, 좀 더 특별한 용도로서 미세기공을 형성하기 위한 미립경량 골재와 같은 용도에서 인산칼슘과 같은 발포제가 사용되 기도 한다[11]. 본 연구에서도 Table 2에서와 같이 일반 선탄경석을 사용한 유리분말을 주원료로 사용하고, 여기 에 탄산칼슘 $\left(\mathrm{CaCO}_{3}\right)$, 인산칼슘 $\left(\mathrm{CaH}_{3}\left(\mathrm{PO}_{4}\right)_{2}\right)$ 을 발포제로 사용하였다. 인산칼슘의 경우에는 분말상 및 액상의 2종 류를 각각 사용하였고, 또한 선탄경석 중에서 석탄분이 많아 카본함량이 높은 셰일 분말을 그대로 카본계 발포 제로 활용하는 실험도 실시하였다. 그 외에 패널형상의 성형체를 제조하기 위한 성형용 바인더로서 규산소다를 사용하였고, 반응 및 열처리온도 조절을 위해 일부 첨가 제를 사용하였다. 유리 및 발포제의 입도가 발포체의 기 공형성에 큰 영향을 미치기 때문에 분말유리 및 광물원 료들은 입도를 균일하게 제어하기 위하여 볼 밀(Ball mill) 로 1 차 분쇄를 하고, 이를 체가름하여 입도를 $0.5 \mathrm{~mm}$ 이하로 조절하여 사용하였다. 주원료인 분쇄된 파유리와 발포제와 같은 부원료를 Table 2에 나타낸 배합비로 배 치 조합한 후 볼 밀을 이용해서 혼합하고 여기에 액상바 인더 및 첨가제를 혼합하였다. 이렇게 제조된 배합원료 를 금속제 몰드에 넣고, 프레스를 이용하여 $15 \mathrm{~kg} / \mathrm{cm}^{2}$ 의 압력으로 가압성형하여 정방형의 시편을 만든 후 건조하 고, 이를 전기로에 넣어 $800^{\circ} \mathrm{C}$ 에서 약 20 분간 열처리 하여 최종 발포체 시편을 제조하였다. 발포유리샘플의 전체적인 실험과정을 Fig. 1에 나타내었다. 각 석탄폐석 및 이를 통해 제조된 파유리의 화학조성은 습식분석 (ICP-OES; OPTIMA 5300 DV, PERKIN-ELMER, USA) 및 기기분석(CS; CS 244, LECO, USA)을 통해 성분분 석을 하였으며, 각 원료들의 열적특성평가를 위해 $\mathrm{TG}-$ DTA(DTG-60H, Shimadzu, Japan)를 이용하여 온도상승 에 따른 열 및 중량변화를 관찰하였다. 또한 유리의 열 적특성을 알아보기 위하여 TMA(Thermomechanical Analyzer: Q400, TA, USA)를 이용하여 열팽창계수를 측정하였고 연화점 측정기(SP-3A, Orton, USA)를 이용 하여 연화점을 측정하였다. 발포체의 기공형상은 실체현

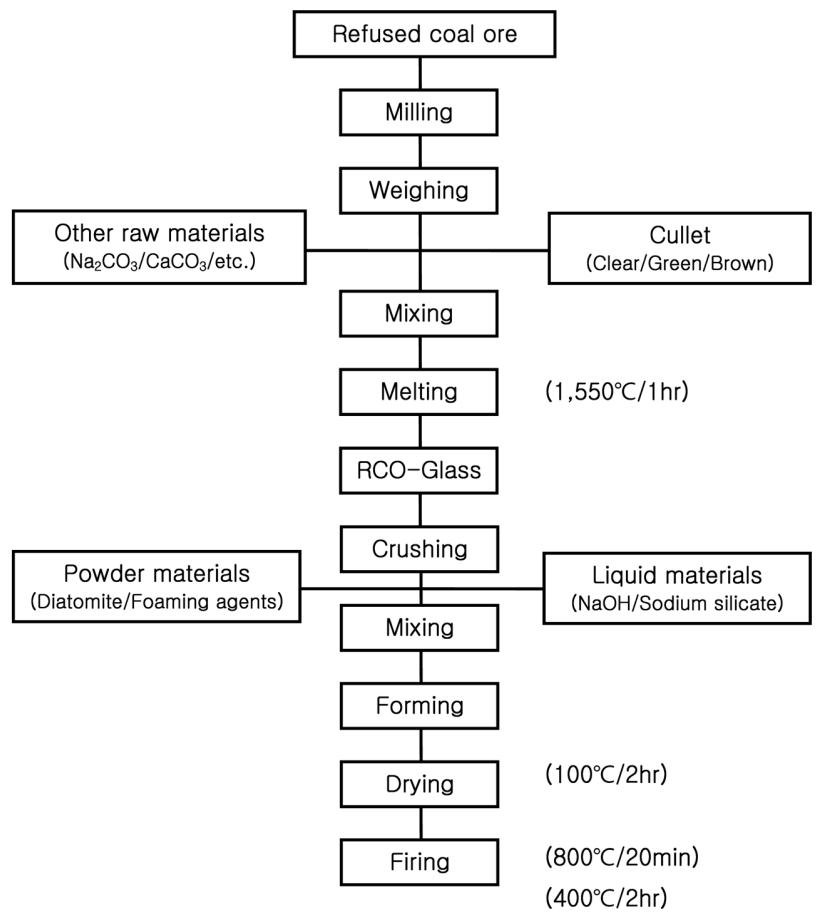

Fig. 1. Experimental procedure for preparing foam glass samples.

미경(BX51, OLYMPUS, JAPAN)을 이용하여 관찰하였 고, 압축강도는 만능시험기(5544, INSTRON, USA)를 이용하여 측정하였다. 발포체의 강도는 발포유리 다공체 시편을 가로, 세로, 높이 각 $15 \mathrm{~mm}$ 의 정육면체로 절단 후 표면을 가공하고 만능시험기를 사용하여 압축강도를 측정하였으며, 압축강도 값은 각각 3 개씩의 시편을 측정 하여 평균값으로 나타내었다.

\section{3. 결과 및 고찰}

\section{1. 석탄폐석 및 석탄폐석활용 유리의 특성}

본 연구에 사용된 석탄폐석의 화학조성분석 결과는 Table 1 에서 볼 수 있듯이 일반 선탄경석의 경우 $\mathrm{SiO}_{2}$ 의 
함량이 $81.1 \%, \mathrm{Al}_{2} \mathrm{O}_{3}$ 의 함량이 $12.0 \%$ 인 것으로 나타났 고, 셰일(shale) 선탄경석의 경우 $\mathrm{SiO}_{2}$ 의 함량이 $70.7 \%$, $\mathrm{Al}_{2} \mathrm{O}_{3}$ 의 함량이 $18.5 \%$ 인 것으로 나타났다. $\mathrm{Fe}_{2} \mathrm{O}_{3}$ 함량 에 있어서는 일반선탄경석이 $0.51 \%$ 인데 비해 셰일 선 탄경석의 경우 $3.37 \%$ 로 큰 차이를 나타내었으며, 특히 셰일 선탄경석의 경우 일반 선탄경석에 비해 육안상으로 훨씬 검은색을 띄고 있었는데, 이는 광물 내에 석탄질, 즉 카본 함량이 상대적으로 높기 때문인 것으로 판단되 었다. 선탄경석을 원료로 제조된 석탄폐석유리(RCOGlass; Refused Coal Ore-Glass)의 경우, $\mathrm{SiO}_{2}$ 가 $71.4 \%$, $\mathrm{Al}_{2} \mathrm{O}_{3}$ 가 $2.71 \%, \mathrm{RO}$ 성분이 $11.05 \%, \mathrm{R}_{2} \mathrm{O}$ 성분이 $14.17 \%$ 로 전형적인 소다석회유리와 유사한 화학조성을 나타내었으며, 유리의 물리적 특성은 열팽창계수 $8.273 \times$ $10^{-6} \%^{\circ} \mathrm{C}$, 연화점(Softening temperature)은 $750^{\circ} \mathrm{C}$ 를 나타 내었다.

\section{2. 발포제 종류별 분해 특성 및 발포 특성}

발포유리의 제조를 위한 발포제로는 보통 탄산칼슘, 카본, 인산칼슘(분말상 및 액상) 등이 많이 사용되고 있 다. 이들 발포제는 온도의 상승에 따라 열분해, 혹은 산 화가 이루어지면서 가스를 발생시키고, 이를 통해 기공 을 형성시킨다. 유리분말과 발포제의 혼합배치가 가열반 응에 따라 다공성의 발포유리가 생성되는 발포매카니즘 에 대해서는 그 동안 일부 논문에서 설명이 되기도 하였 으나, 이를 모식도를 이용하여 다시 나타내보면 Fig. 2 와 같다[6]. 그림에서 볼 수 있듯이 유리분말과 발포제 가 함께 혼합되어 있는 상태에서 열처리에 의해 온도가 상승하면 입자들간의 치밀화 과정(Densifying step)이 진 행되고, 분말 원료 사이의 기공들이 차단되게 된다. 충분 한 치밀화가 이루어진 상태(Densified step)에서 온도가

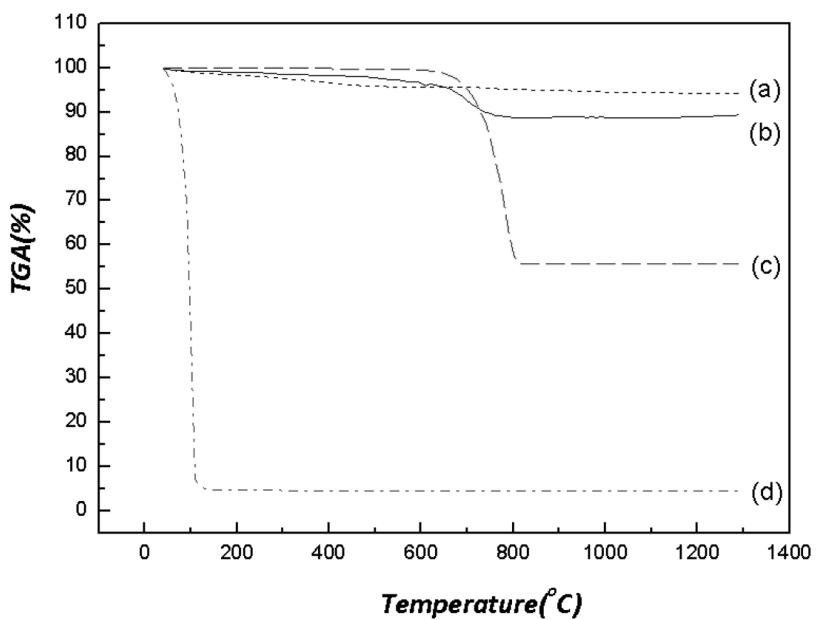

Fig. 3. TGA curve of foaming agents include shale powder of refused coal ore. (a) Calcium phosphate (powder), (b) Shale powder (refused coal ore), (c) Calcium carbonate, (d) Calcium phosphate (solution).

유리의 연화점 이상으로 가열되면 분말유리가 고점도의 액상상태가 되고, 온도상승에 따라 발포제가 분해되면서 가스가 발생하게 되면 밀폐된 가스가 액상유리 내에서 새로운 기공을 형성하고 성장하면서 다공체를 형성하게 된다. 이 과정에서 가스의 발생량 및 분압에 따라 액상 유리 내에서 외부로 가스가 분출되면서 개기공(Open pore)상태가 되기도 하고, 그냥 가스가 기공내부에 포집 된 밀폐기공(Closed pore) 상태로 유지 되기도 한다.

따라서 본 실험에 사용된 각종 발포제의 온도에 따른 열적 분해특성을 알아보기 위하여 TG-DTA를 이용하여 상온에서 $1300^{\circ} \mathrm{C}$ 까지 온도상승에 따른 변화를 측정하고, TGA 그래프를 Fig. 3에 나타내었다. 고체인산칼슘의 경 우 그래프 (a)에서 볼 수 있듯이 비교적 온도에 따른 감 량변화가 급격하게 일어나지 않고 미량씩 꾸준히 발생하

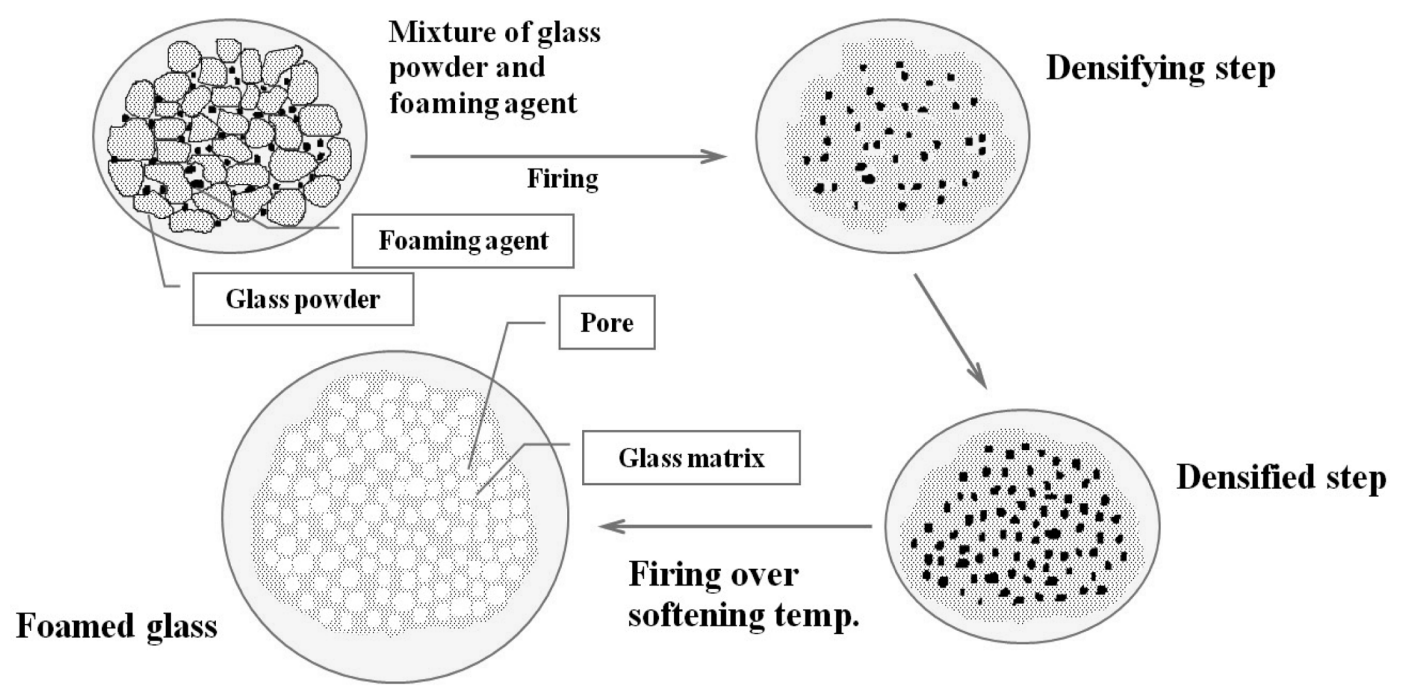

Fig. 2. Foaming mechanism of foam glass sample during heat treatment. 
고 있으며, $1200^{\circ} \mathrm{C}$ 까지 약 $6 \%$ 정도 감량이 일어나는 것으로 나타났다. 석탄폐석의 한 종류인 셰일 선탄경석 의 경우 그래프 (b)에서와 같이 광물 내에 함유된 탄소 분의 산화로 인해 감량이 서서히 발생하였고, 650 $750^{\circ} \mathrm{C}$ 범위에서는 좀 더 급격한 감량이 발생하면서 최 종적으로 약 $11 \%$ 정도의 감량이 일어나는 것으로 나타 났다. 탄산칼슘의 경우는 그래프 (c)에서 볼 수 있듯이 약 $500^{\circ} \mathrm{C}$ 에서부터 분해가 일어나면서 감량이 시작되어 $820^{\circ} \mathrm{C}$ 까지 약 $45 \%$ 의 감량이 되는 것으로 나타나고 있 으며, 특히 $700 ~ 800^{\circ} \mathrm{C}$ 범위에서 급격한 변화가 발생하 였다. 액체인산칼슘의 경우는 그래프 (d)에서 볼 수 있 듯이 $100^{\circ} \mathrm{C}$ 까지 액상의 증발이 이루어지면서 약 $125^{\circ} \mathrm{C}$ 까지 $98.5 \%$ 의 감량이 발생하고, 그 이후 고형분 잔량에 서 일부 추가 감량이 약 $0.2 \%$ 발생하여 최종적으로는 $98.7 \%$ 의 감량이 발생하는 것으로 나타났다. 이와 같이 발포제의 종류에 따라 발포제의 분해 시작온도 및 종료 온도가 달라지며 유리의 조성에 따라 유리의 연화온도가 다르므로, 양호한 발포체를 얻기 위해서는 이 두 원료간 의 상호 열적특성상 매칭이 잘 이루어지도록 하는 것이 매우 중요하다[7]. 만약 동일한 특성의 유리분말을 원료 로 사용하는 경우에는 결과적으로 사용한 발포제의 종류
와 함량에 따라 형성되는 기공의 형태 및 크기가 큰 차 이를 나타내게 된다[8]. 일반적으로 탄산칼슘 발포체에 의해 형성되는 기공은 기공의 크기가 크고, 형상이 불규 칙하며 주로 개기공(Open pore)을 나타내고, 카본 및 人 山칼슘에 의해 형성되는 기공은 상대적으로 기공의 크기 가 작고 균일하며 폐기공(Closed pore)을 형성하게 된다. 본 실험에서는 발포제의 종류별 특성비교를 목적으로 하 였기 때문에 발포를 위한 열처리 조건을 고정시켜 실험 하였고, 이러한 각 발포제의 분해 및 발포특성을 고려하 여 열처리 온도를 $800^{\circ} \mathrm{C}$ 로 결정하였으며, 따라서 모든 발포제에서 최적의 발포 조건이라고 할 수는 없으나 비 교적 모든 시편에서 양호한 특성을 나타내는 발포체를 얻을 수 있었다.

\section{3. 발포제 종류별 발포유리의 기공 특성}

Fig. 4에 발포제의 종류별 발포 다공체 시편의 기공 특성 사진을 나타내었다. 발포를 위한 열처리 과정에서 모든 시편들의 표면 외관은 표면의 유리질이 융착되어 기공이 없는 치밀한 표면상태를 나타내므로, 각 시편들 의 내부기공 관찰을 위해 시편을 다이아몬드 휠로 절단

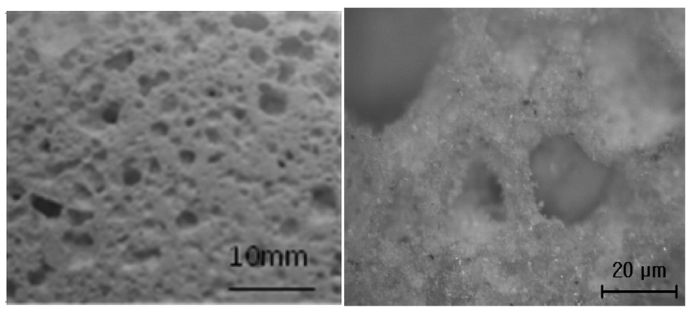

(a)

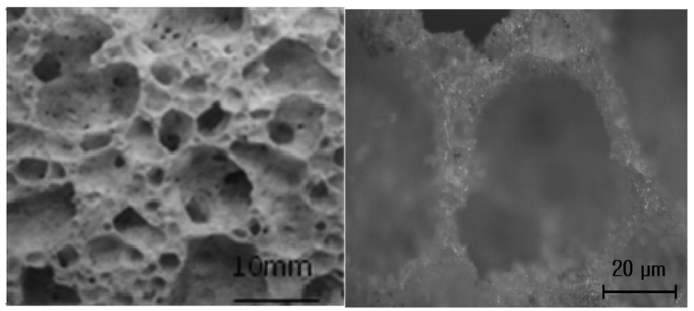

(c)

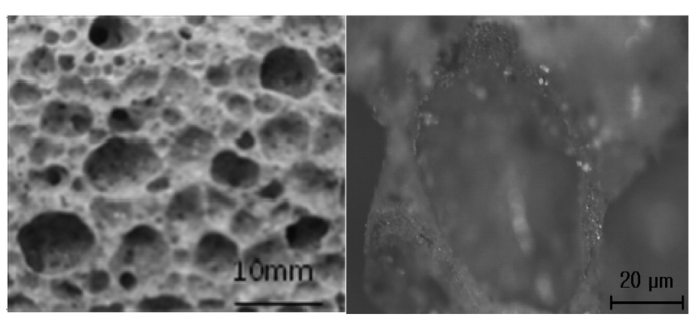

(e)

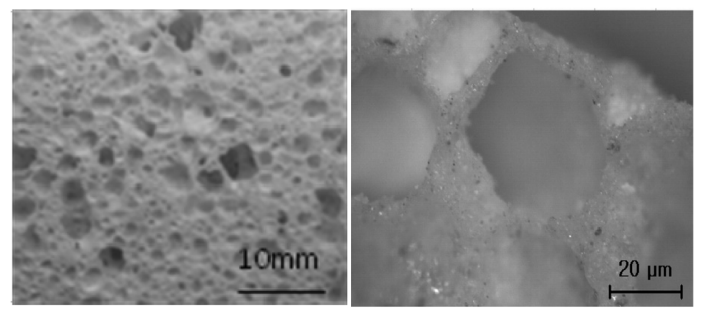

(b)

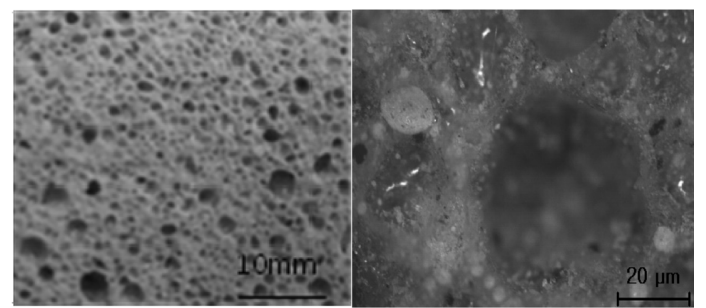

(d)

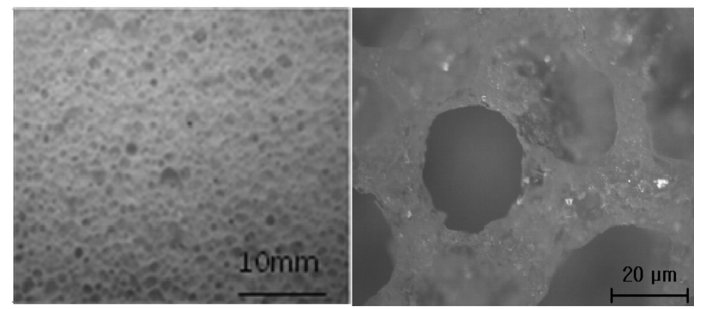

(f)

Fig. 4. Pore structure of each foam glass samples by using various kinds of foaming agents. (a) NG-C/Pp, (b) RCO-C/Pp, (c) RCO-C/S, (d) RCO-S/Pp, (e) RCO-S, (f) RCO-Ps. 
한 후 별도의 연마처리 없이 전체의 발포상태를 대표할 수 있는 부위를 선택하여 실체현미경으로 관찰하였다. 각 시편의 왼쪽 그림은 3.5 배로 찍은 시편의 표면기공 사진이며, 오른쪽은 500 배의 현미경사진이다. (a)는 소다 라임계 일반 파유리에 발포제로 탄산칼슘과 인산칼슘을 $1: 1$ 로 사용한 시편이며, (b)는 동일한 발포제를 사용하 면서 일반 파유리를 석탄폐석유리로 대체한 시편의 사진 이다. 기공의 형태나 크기 상으로 거의 차이가 없이 유 사한 형상을 나타내는 것을 알 수 있었으며, 따라서 석 탄폐석유리를 발포유리 원료로 대체 사용하여도 발포유 리 다공체의 특성에는 큰 영향을 미치지 않는 것을 알 수 있었다. 다만 탄산칼슘 발포체가 앞에서 언급한 바와 같이 대형기공을 형성하고, 인산칼슘 발포체가 소형기공 을 형성함으로 인해 크기가 서로 다른 다양한 기공이 형 성되어 있는 것을 볼 수 있었으며, 특히 대형기공들은 형상이 불규칙하면서 개기공의 형태를 나타내고 있는 것 을 알 수 있었다. (c)는 석탄폐석유리에 발포제로 탄산칼 슘과 셰일 분말을 사용한 시편으로 여기서는 더욱 크고 불규칙한 기공들이 형성되어 있으며, 큰 기공의 내부에 도 작은 기공들이 많이 겹쳐있음을 볼 수 있는데, 이는 탄산칼슘이 대형기공을 형성하면서 동시에 셰일 분말 내 에 있는 카본 성분이 미세한 기공을 형성하면서 약 $800^{\circ} \mathrm{C}$ 이상까지 계속 급격한 분해가 이루어져 기공이 크게 성 장되었기 때문인 것으로 판단된다. 반면에 발포제로 셰 일 분말과 인산칼슘을 사용한 시편 (d)의 경우는 인산칼 슘 발포제가 형성하는 기포의 특성상 비교적 작고 균일 한 기공이 형성되어 있는 것을 볼 수 있었다. 또한 발포 제로 셰일 분말 만을 사용한 시편 (e)의 경우에는 기공 의 크기는 크지만 카본 발포체가 갖는 특징상 비교적 기 공의 형상이 원형이고 폐기공의 형태를 보이고 있으며, 기포벽이 두꺼운 상태를 나타내고 있음을 알 수 있었다. 발포제로 액체인산칼슘을 사용한 시편 (f)의 경우에는 그림에서와 같이 매우 작고 균일한 기공들이 규칙적으로 배열되어 있는 것을 알 수 있는데, 이는 실제적으로 액 체인산칼슘이 액상으로 투입되면서 미세한 발포제가 균 일하게 분포된 상태에서 미량의 결정수 만에 의해 발포 가 이루어지기 때문에 균일한 기공이 형성되고, 또한 기 공의 성장이 크게 이루어지지 않았기 때문에 이러한 형 태를 유지하는 것으로 판단된다. 특히 기공의 크기가 작 으면서도 균일하게 분포를 하고 있기 때문에 비중이 낮 으면서도 파괴강도가 높은 양호한 발포유리 다공체를 제 조하는데 아주 바람직할 것으로 판단되었다.

\section{4. 발포제 종류별 발포유리의 비중특성}

발포제의 종류에 따른 각 시편들의 비중을 측정하여 이를 Fig. 5에 나타내었다. 전체적으로 시편의 비중은

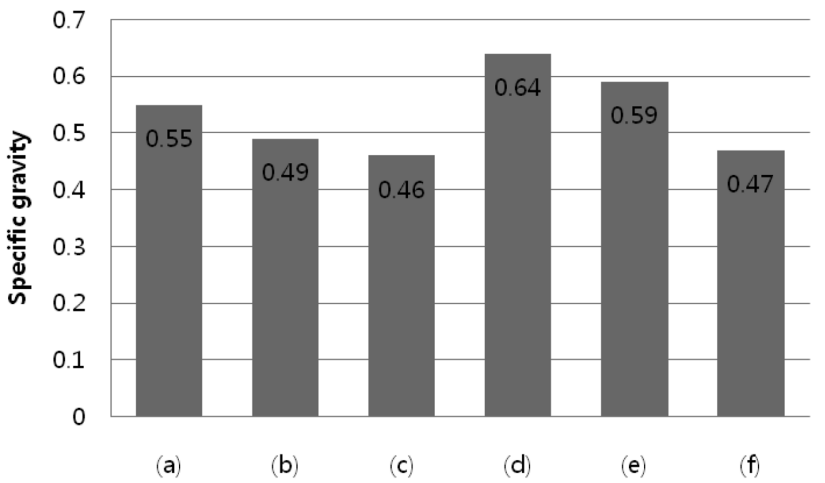

Fig. 5. Specific gravity of foam glass samples. (a) NG-C/Pp, (b) RCO-C/Pp, (c) RCO-C/S, (d) RCO-S/Pp, (e) RCO-S, (f) RCO-Ps.

발포제의 종류에 상관없이 발포제를 전체 배합비의 약 $10 \%$ 정도 사용한 상태에서 평균 0.5 정도의 값을 나타 내었으며, 종류별로 0.46 0.64의 값을 나타내었다. 앞서 기공의 형상분석에서 언급했듯이 소다라임계 일반 파유 리 분말과 석탄폐석 유리 분말 간에 발포특성상에 별 차 이가 없었으므로 시편의 비중에 있어서도 큰 차이를 나 타내지 않았으며, 기공의 크기와 상관없이 비중 값은 비 슷한 경향을 나타내었다. 다만 셰일 분말을 발포제로 사 용한 경우에는 발포제 역할을 하는 셰일 분말 내 카본의 함량이 타 시편에 비해 상대적으로 낮음으로 인해 비중 이 약간 높게 나타나는 것을 알 수 있었다. 반면에 액체 인산칼슘을 발포제로 사용한 시편 (f)의 경우 Fig. 4에서 는 기공의 크기가 상대적으로 매우 작고 미세한 형태를 나타내고 있어서 기공율이 적은 것으로 보이나 기공이 시편 전체에 균일하게 규칙적으로 분포됨으로써 실제 비 중은 0.47 로 매우 낮은 비중 값을 나타내어 발포유리 다 공체로써의 매우 양호한 특성 값을 나타내었다.

\section{5. 발포제 종류별 발포유리의 강도특성}

발포제의 종류에 따른 발포유리 다공체 시편을 가로, 세로, 높이 각 $15 \mathrm{~mm}$ 의 정육면체로 가공하고 만능시험 기를 사용하여 압축강도를 측정하였으며, 압축강도 값은 발포제의 종류에 따른 시편의 종류에 따라 $30 \sim 72 \mathrm{~kg} /$ $\mathrm{cm}^{2}$ 의 값을 나타내었다. 일반적으로 발포유리의 강도특 성은 비중 및 기공의 크기와 밀접한 상관관계를 나타낸 다[8]. T.Y. Lim 등이 탄산칼슘과 인산칼슘을 발포제로 사용한 동일 조성계의 발포유리 연구에 의하면 비중이 0.45 0.60 범위에서 비중이 0.05 씩 증가함에 따라 강도 가 $20 \mathrm{~kg} / \mathrm{cm}^{2}$ 에서 약 $50 \%$ 씩 평균적으로 증가하는 것으 로 나타나 있다[11]. 석탄폐석유리로 제조한 발포유리 시편의 경우, 발포제로서 탄산칼슘과 인산칼슘을 $1: 1$ 의 비율로 혼합 사용한 시편에서는 기존의 정상적인 파유리 


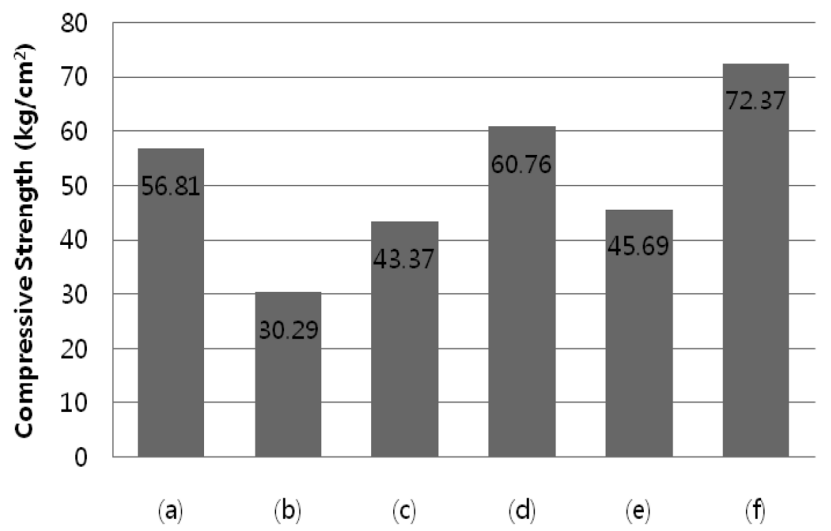

Fig. 6. Compressive strength of foam glass samples. (a) NG-C/ $\mathrm{Pp}$, (b) RCO-C/Pp, (c) RCO-C/S, (d) RCO-S/Pp, (e) RCO-S, (f) RCO-Ps.

로 제조한 발포유리와 비교하여 약 $40 \%$ 이상의 강도하 락이 발생하였으나, 이는 비중이 상대적으로 0.06 정도 낮아짐으로써 비중차이에 의한 영향도 작용한 것으로 판 단되며, 반면에 발포제로 셰일 분말과 인산칼슘분말을 사용한 경우에는 오히려 우수한 강도 특성을 나타내었다. 특히 액체인산칼슘을 발포제로 사용한 시편에 있어서는 정상적인 파유리 사용 시편에 비해 비중 값이 0.47 로 0.08 만큼 낮은 데도 불구하고 압축강도가 약 $25 \%$ 이상 높은 $72 \mathrm{~kg} / \mathrm{cm}^{2}$ 의 강도 값을 나타내어 발포 다공체로서 매우 양호한 특성을 나타내었다. 따라서 이러한 특성 값 은 기존의 ALC(Autoclaved Lightweight Concrete) 무 기단열재가 갖는 비중 $0.5 \sim 0.6$, 압축강도 $30 \sim 50 \mathrm{~kg} / \mathrm{cm}^{2}$ 의 특성보다 전반적으로 훨씬 양호한 물성을 나타내고 있으므로, 향후 건축용 단열재나 내장재로서 큰 응용가 능성이 기대됨을 판단할 수 있었다.

\section{4. 결 론}

삼척 도계탄광지역에서 발생하는 석탄폐석을 주원료로 만든 석탄폐석유리와 발포제를 이용하여 발포유리를 제 조하는 연구를 진행하였다. 석탄폐석유리는 소다라임계 유리를 제조한 후 분쇄하여 분말유리상태로 활용하였고, 발포제는 탄산칼슘, 인산칼슘(분말상 및 액상) 및 셰일 선탄경석 자체 분말을 이용하였다. 이들 원료에 액상의 바인더를 첨가하여 판상으로 성형한 후 열처리하여 발포 다공체를 제조하고, 이들 시편의 비중, 기공구조와 함께 압축강도를 측정하여 비교한 결과 다음과 같은 결론을 얻을 수 있었다.

석탄폐석을 주원료로 만들어진 유리에 발포제와 타 원 료들과 혼합한 후 성형하여 $800^{\circ} \mathrm{C}$ 에서 열처리 한 결과 비중 $0.4 \sim 0.7$, 압축강도 $30 \sim 72 \mathrm{~kg} / \mathrm{cm}^{2}$ 를 갖는 발포유리
다공체를 얻을 수 있었다. 이들은 발포제의 종류에 따라 각기 다른 특성의 기공구조를 나타내었으며, 석탄폐석의 한 종류인 셰일 선탄경석 분말 자체를 발포제로 사용한 경우에도 충분히 만족스러운 발포 다공체를 얻을 수 있 었고, 특히 액체인산칼슘을 발포제로 사용한 경우에는 매우 미세하고 규칙적인 기공구조를 갖는 발포유리 다공 체가 만들어졌고, 비중 0.47 의 매우 낮은 비중 값을 나 타내면서도 압축강도 $72 \mathrm{~kg} / \mathrm{cm}^{2}$ 의 매우 높은 강도 값을 갖는 양호한 특성의 발포유리제품을 제조할 수 있었다. 또한 석탄폐석유리가 아닌 일반 소다라임계 정상 파유리 를 원료로 사용한 발포유리 시편이나 기존의 $\mathrm{ALC}$ 와 같 은 무기 단열재 제품과 비교하여도 동등 이상의 물성을 갖는 시편을 제조할 수 있었다. 따라서 본 연구를 바탕 으로 석탄폐석을 주원료로 만들어진 석탄폐석유리를 이 용하여 유리 2차 제품의 하나인 건축용 및 산업용 발포 유리 패널의 제조 및 응용이 충분히 가능할 것으로 판단 되었다.

\section{감사의 글}

본 논문은 지식경제부의 지역연고산업육성사업인 '삼 척 유리질석탄폐석(도계글라스)을 활용한 유리제품 산업 화 사업'에 의해 수행된 연구입니다.

\section{참 고 문 헌}

[1] S.B. Jeong, "Effective utilization for the domestic coal refuse", Korea Insititute of Geoscience \& Mineral Resources (2005).

[2] B.S. Kim, "Development of a pyrometallurgical process for recovering precious metals simultaneously from the ovsolete printed circuit boards (PCBs) \& spent autocatalysts", Annual Report, Korea Insititute of Geoscience \& Mineral Resources (2002) 10.

[3] Y. Ryu and Y. Kim, "A study on the surface modification of artificial lightweight aggregates by using bottom ash from coal power plant", J. Kor. Crystal Growth and Crystal Technology 19 (2009) 208.

[ 4 ] M. Song, J.B. Jang, B.S. Cho, J.H. Kim, Y.R. Kim and M.H. Kim, "An experimental study on properties of mortar using bottom ash produced in power plant", J. Architectural Institute of Korea 23 (2003) 202.

[5] K.D. Kim and S.G. Kang, "Manufacturing artificial lightweight aggregates using coal botom ash and clay", J. Kor. Crystal Growth and Crystal Technology 17 (2007) 277.

[6] C.-T. Lee, "The recycling of waste glass - manufacture of foamglass and its prospect", Prospectives of Industrial Chemistry 3(2) (2000) 1.

[7] C.-T. Lee, "Physical and chemical properties of waste glass as feed materials for the production of foamed 
glass", J. Korean Ind. Eng. Chem. 16(3) (2005) 440.

[ 8 ] H.Y. Cho, H.J. Kim, P.K. Chang, C.H. Choi and S.W. Lee, "A Study on the physical characteristis of foaming glass by recycling waste glass", J. Korea Academia Ind. Co. Soc. 6(6) (2005) 473.

[9] T.Y. Lim, S.S. Jeong, J.H. Hwang and J.H. Kim, "A study on the fabrication of soda-lime glass by using refused coal ore and its properties", J. Korean Crystal Growth and Crystal Technology 20(1) (2010) 43.
[10] T.Y. Lim, S.S. Jeong, J.H. Hwang, J.H. Kim and J.K. Kim, "Optical properties of soda-lime color glass fabricated by using refused coal ore", Kor. J. Mater. Res. 20(10) (2010) 524.

[11] T.Y. Lim, Y.M. Park, J.H. Hwang, C.Y. Kim and C.Y. Kim, "Fabrication and characterization of porous ceramic panel using recycled glass powder", Material Science Forum 510-511 (2006) 642. 